\title{
First report of erythrocytic inclusion body syndrome (EIBS) in chinook salmon Oncorhynchus tshawytscha in Alaska, USA
}

\author{
Theodore R. Meyers* \\ Alaska Department of Fish and Game, Commercial Fisheries Division, Juneau Fish Pathology Laboratory, \\ PO Box 25526, Juneau, Alaska 99802-5526, USA
}

\begin{abstract}
Juvenile seawater-reared chinook salmon Oncorhynchus tshawytscha at a hatchery on Baranoff Island, Alaska, USA, sustained chronic mortality associated with anemia and mixed infections by various obligate and opportunistic pathogens including a cytoplasmic erythrocytic virus resembling the agent of erythrocytic inclusion body syndrome (EIBS). This is the first case report of EIBS in Alaska and is a range extension of the disease.
\end{abstract}

KEY WORDS: Erythrocytic inclusion body syndrome $\cdot$ EIBS $\cdot$ Anemia $\cdot$ Chinook salmon

\section{INTRODUCTION}

Erythrocytic inclusion body syndrome (EIBS) was first described in freshwater-reared juvenile spring chinook salmon Oncorhynchus tshawytscha from the Little White Salmon National Fish Hatchery in Cook, Washington, USA, in 1982 (Leek 1987). EIBS was later described in chinook and coho salmon O. kisutch throughout Washington and parts of Oregon, California (Piacentini 1989), and Idaho (Foott et al. 1992). The known geographic and natural host range of the virus expanded to include seawater-reared coho salmon in Japan (Takahashi et al. 1992), freshwater-reared Atlantic salmon Salmo salar in Norway (Lunder et al. 1990), and freshwater and seawater-reared Atlantic salmon and rainbow trout O. mykiss from the British Isles (Rodger et al. 1991, Rodger \& Richards 1998). Other salmonid species showing variable susceptibilities by experimental injection with infected blood homogenates include cutthroat trout $O$. clarki (Piacentini et al. 1989), masou salmon O. masou, and chum salmon O. keta (Okamoto et al. 1992).
Typical EIBS presents with single or multiple pale, basophilic, cytoplasmic inclusions $(0.4$ to $1.6 \mu \mathrm{m}$; Michak et al. 1992) in erythrocytes that are observed in stained peripheral blood smears. Affected fish may be asymptomatic, but more often they have varying degrees of anemia and secondary bacterial and fungal infections. In severe cases of uncomplicated anemia, cumulative fish mortality of over $20 \%$ has been reported where hematocrit values were less than $20 \%$ in seawater-reared coho salmon in Japan (Takahashi et al. 1992). The disease can be transmitted horizontally, while surviving fish generally recover and develop an acquired immunity against reinfection that is transferable by passive immunization (Piacentini et al. 1989). Five stages of the disease have been described: pre-inclusion, inclusion body formation, cell lysis with low hematocrit values, recovery with increasing hematocrit values, and full recovery (Piacentini et al. 1989). The causative agent is an icosahedral virus approximately 70 to $80 \mathrm{~nm}$ in diameter occurring freely in the cytoplasm or more commonly in membrane-bound cytoplasmic inclusion bodies within 
erythrocytes (Leek 1987, Michak et al. 1992). Isolation and replication of the virus in available fish cell lines has been unsuccessful, thus preventing further characterization. A more recent study of an epizootic in Atlantic salmon (Graham et al. 2002) reported EIBSlike inclusions and virus particles in erythrocytes as well as similar virus particles associated with necrosis in hematopoietic tissues of the spleen and kidney and hyperplasia of gill tissues. The histopathology and virus were morphologically similar to the previously described phagocytolytic syndrome (PCLS) in Atlantic salmon (Palmer et al. 1992). Graham et al. (2002) suggested that EIBS and PCLS may represent alternate or concurrent manifestations of infection by the same virus. The EIBS virus has also been associated with heart and skeletal muscle inflammation in Atlantic salmon from western Norway where typical virus particles were present in vacuoles within erythrocytes and unidentified head kidney cells (Watanabe et al. 2006). This note presents a case study of the first report of EIBS in Alaska, which represents a range extension of the disease.

\section{MATERIALS AND METHODS}

Case history. A salmon hatchery on Baranof Island near Sitka, Alaska, sustained ongoing chronic mortality in brood year 2002 juvenile chinook salmon in late October after transfer to seawater net pens in September 2003. The immediate cause of the fish mortality was diagnosed as vibriosis and was successfully treated by dietary administration of oxytetracycline (OTC). By late December 2003 through early March 2004, additional disease outbreaks in these fish included furunculosis and low level bacterial kidney disease (BKD). Fish mortality was 120 to 400 fish $\mathrm{d}^{-1}$ within a population of 1.25 million fish in 6 net pens. Isolates of Aeromonas salmonicida were resistant to OTC and marginally sensitive to Romet B. Therefore, Romet was not used for treatment due to concerns over less than optimum sensitivity to this antibiotic. Instead, the freshwater lens in each pen was removed, and larger net pens were deployed to optimize the rearing environment. Mortality continued in the smaller fish and was higher than could be expected from osmoincompetency.

In early April through May 2004, fish mortality escalated again $\left(0.3 \% \mathrm{~d}^{-1}\right)$. Smolt size ranged from 10 to $50 \mathrm{~g}$ total weight, and $50 \%$ of the mortality occurred in larger fish over $20 \mathrm{~g}$. The seawater temperature was $5^{\circ} \mathrm{C}$, fish were lethargic, and the feeding response was poor. Hatchery staff switched to another brand of feed that appeared to be more palatable to the fish. Juvenile chinook salmon from this latest mortality were submit- ted for necropsy to the Alaska Department of Fish and Game (ADFG) fish pathology laboratory in Juneau.

Necropsy. Necropsies were performed as previously described (Meyers 2000) after fish were euthanized with an overdose $\left(1000 \mathrm{mg} \mathrm{l}^{-1}\right)$ of sodium bicarbonate buffered tricaine methanesulfonate (Callahan \& Noga 2002). Briefly, each necropsy included microscopic examination of 30 fields at $200 \times$ magnification of wetmounted gill tissues, skin scrapes, and spleen and gut squashes. Peripheral blood from severed caudal peduncles was smeared onto glass slides, air-dried, and stained with Diff-Quik for examination of 30 fields under oil immersion (1000× magnification). After microscopic examination, cover slips were removed from wet mounts of gill and skin for Gram-staining and further examination of 30 fields under oil immersion. Smears of kidney tissues in phosphate buffered saline were made on multiple well $(7 \mathrm{~mm})$ slides and stained by direct fluorescent antibody (DFAT) for the detection of Renibacterium salmoninarum (Meyers et al. 1993).

Microbiology. Kidney tissues were aseptically inoculated onto plates of tryptic soy agar with and without $2 \% \mathrm{NaCl}$ and incubated at $20^{\circ} \mathrm{C}$. Sub-cultured lawns of isolates were tested for antibiotic disc sensitivities on Mueller-Hinton agar (Burton et al. 2000). Bacterial isolates were identified with the API-20E biochemical system (Santos et al. 1993) in combination with standard biochemical tests and serological confirmation of Listonella (Vibrio) anguillarum and Aeromonas salmonicida using BIONOR Mono-kit latex agglutination (Romalde et al. 1995).

Hematocrit. As part of routine fish condition profiling (Goede \& Barton 1990), the hatchery staff determined hematocrit values using the standard microhematocrit method after collecting blood from severed caudal peduncles of anesthetized fish.

Table 1. Oncorhynchus tshawytscha. Clinical findings for seawater-reared juvenile chinook salmon examined from Baranof Island, Alaska, in April and May 2004. Prevalence indicates the number infected/ number fish examined on 9 April 2004 except where footnoted

\begin{tabular}{|lc|}
\hline Clinical findings & Prevalence \\
\hline Ichthyobodo sp. - gill & $2 / 5$ \\
Filamentous bacteria - skin/gill & $4 / 5$ \\
Renibacterium salmoninarum - DFAT & $1 / 9$ \\
Aeromonas salmonicida - BIONOR & $3 / 9$ \\
Mean \% hematocrit & $30(11-41)$ \\
EIBS - Diff Quik & $2 / 5$ \\
& $2 / 15^{\mathrm{b}}$ \\
Blast/immature RBC-Diff Quik & $6 / 15^{\mathrm{b}}$ \\
${ }^{\mathrm{a}} \mathrm{N}=11$ fish examined by hatchery staff on 13 April 2004 \\
with range of values in parentheses. Mean length/weight \\
$=127$ mm/23.7 g \\
${ }^{\mathrm{b}}$ Fish examined on 4 May 2004 \\
\hline
\end{tabular}


Transmission electron microscopy (TEM). During necropsies at the ADFG laboratory, blood was collected in microhematocrit capillary tubes from each numbered fish for later fixation of those samples corresponding to EIBS-type inclusion bodies detected in the respective blood smears. Selected heparinized blood was fixed overnight at $4^{\circ} \mathrm{C}$ in $4 \%$ glutaraldehyde in $0.1 \mathrm{M}$ cacodylate buffer ( $\mathrm{pH} 7.8$ ), post fixed in cacodylate buffered $1 \%$ osmium tetroxide for $1 \mathrm{~h}$ at room temperature, then dehydrated through a series of ethanol solutions and embedded in Spurr's resin. Ultrathin sections on 300 mesh slotted copper grids were stained in $2 \%$ aqueous uranyl acetate and $2.6 \%$ lead citrate and examined on a Philips EM 300 at $60 \mathrm{kV}$. other opportunistic pathogens such as external bacteria. Lastly, EIBS alone can be an underlying stressor often associated with mixed pathogen etiologies as reported elsewhere (Piacentini et al. 1989).

Of particular interest was the presumptive EIBS, a disease not previously observed in Alaskan salmonids. Ultrastructural examination of erythrocytes from one fish having single and multiple cytoplasmic erythrocytic inclusions in peripheral blood (Fig. 1A) demonstrated unenveloped 60 to $70 \mathrm{~nm}$ icosahedral virus particles associated with the inclusions (Fig. 1B,C) and also occurring extracellularly among cell debris (Fig. 1D). Some of the fish examined in early April had pale gills and mottled kidneys sug-

\section{RESULTS AND DISCUSSION}

Table 1 summarizes the clinical results of juvenile chinook salmon examined by ADFG pathologists on 9 April and 4 May and by hatchery staff on 13 April 2004. The diagnosis included OTC resistant but Romet B sensitive furunculosis, low-level BKD (only 1 of 9 kidneys with 1 to 5 fluorescing bacteria in 30 fields), gill infestation by Ichthyobodo, external gill and skin filamentous bacterial infections, anemia, and presumptive EIBS. The current fish mortality was due to a complex of several etiologies of both obligate and opportunistic pathogens with no single agent clearly dominant. Early stressors such as osmo-incompetency in the smaller fish together with poor feeding response to an unpalatable diet may have set the stage for the variety of pathogens encountered. The Ichthyobodo parasite on the gills may also have been significant. Previous freshwater infestations can persist in the freshwater lens of a net pen once fish are transferred to seawater, and Bruno (1992) reported a marine Ichthyobodo. Regardless of its origin, Ichthyobodo infestations can cause poor seawater adaption of smolts (Urawa 1993), which can exacerbate subclinical infections of obligate pathogens such as Aeromonas salmonicida and Renibacterium salmoninarum, causing additional mortality and predisposition to infection by
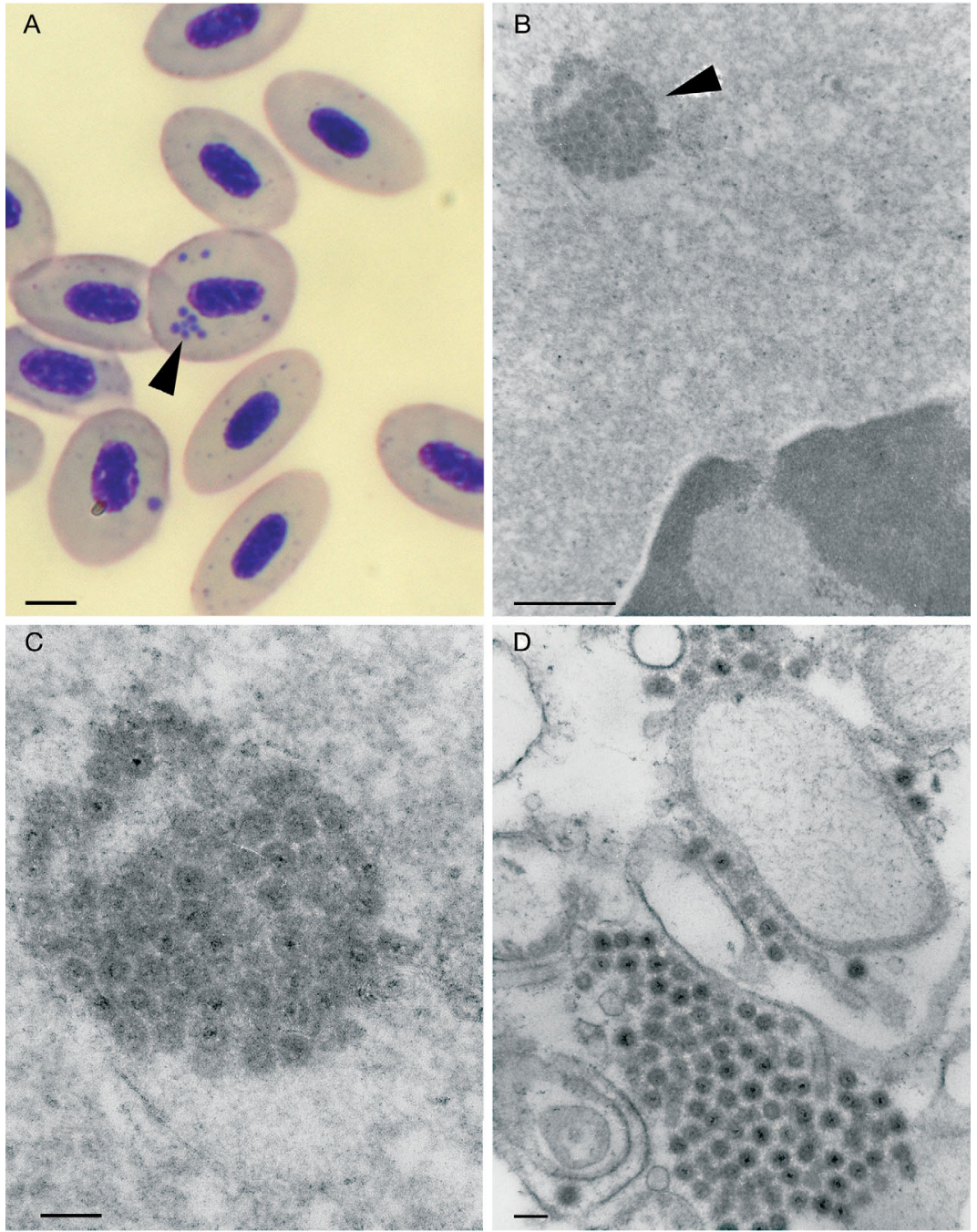

Fig. 1. EIBS virus in Oncorhynchus tshawytscha. (A) Peripheral blood smear with single and multiple cytoplasmic erythrocytic inclusion bodies (arrowhead). Scale bar $=5 \mu \mathrm{m}$. (B) TEM of a single virus inclusion body (arrowhead) in erythrocyte cytoplasm. Scale bar $=0.5 \mu \mathrm{m}$. (C) Magnification of virus particles (60 to $70 \mathrm{~nm}$ ) in the inclusion body of (B). Scale bar $=100 \mathrm{~nm}$. (D) Extracellular virus particles associated with cell debris in peripheral blood. Scale bar $=100 \mathrm{~nm}$ 
gesting anemia, which was further supported by sufficiently low hematocrit values collected at the hatchery $4 \mathrm{~d}$ later. However, by this time the fish may have passed the nadir of the anemia, as suggested by signs of recovery in the blood smears (Table 1) that included few inclusion bodies and large numbers of blast cells and immature erythrocytes (Piacentini et al. 1989). It also could not be confirmed that the anemia was entirely caused by EIBS due to the presence of other primary pathogens causing clinical disease and fish mortality. The virus particles observed were smaller than typically reported for EIBS elsewhere and were more frequently associated with cell debris in the peripheral blood, most likely resulting from lysis of infected erythrocytes.

At the end of April, fish were fed a $7 \mathrm{~d}$ regimen of Romet for the furunculosis, but the fish in 3 net pens were released early in May due to continued high mortality. The remaining pens appeared to respond well to Romet therapy and were released on schedule in early June.

In summary, EIBS-type virus particles were found producing typical intraerythrocytic inclusions in seawater-reared juvenile chinook salmon at a hatchery on Baranof Island, Alaska. The fish were anemic and sustained infections by other pathogens. The virus particle size was slightly smaller than reported elsewhere but represents a range extension of the disease to include Alaska, USA.

Acknowledgements. I thank the staff at Hidden Falls Hatchery for their help in obtaining hematocrit data and necropsy samples.

\section{LITERATURE CITED}

Bruno DW (1992) Ichthyobodo sp. on farmed Atlantic salmon, Salmo salar L., reared in the marine environment. J Fish Dis 15:349-351

Burton T, Follett J, Short S, Lipson K (2000) Bacteriology. In: Meyers TR (ed) Fish pathology section laboratory manual, 2nd edn. Comm Fish Div, Alaska Dept Fish and Game, Juneau, AK, p 4-1-4-25

Callahan HA, Noga EJ (2002) Tricaine dramatically reduces the ability to diagnose protozoan ectoparasite (Ichthyobodo necator) infections. J Fish Dis 25:433-437

Foott JS, Miller A, Steiner R, Hedrick RP (1992) Erythrocytic inclusion body syndrome (EIBS) infection of chinook salmon in Idaho. J Aquat Anim Health 4:306-308

Goede RW, Barton BA (1990) Organismic indices and an autopsy-based assessment as indicators of health and condition of fish. Am Fish Soc Symp 8:93-108

Graham DA, Curran W, Rowley HM, Cox DI, Cockerill D, Campbell S, Todd D (2002) Observation of virus particles in the spleen, kidney, gills and erythrocytes of Atlantic salmon, Salmo salar L., during a disease outbreak with high mortality. J Fish Dis 25:227-234

Leek SL (1987) Viral erythrocytic inclusion body syndrome (EIBS) occurring in juvenile spring chinook salmon (Oncorhynchus tshawytscha) reared in freshwater. Can J Fish Aquat Sci 44:685-688

Lunder T, Thorud K, Poppe TT, Holt RA, Rohovec JS (1990) Particles similar to the virus of erythrocytic inclusion body syndrome, EIBS, detected in Atlantic salmon (Salmo salar) in Norway. Bull Eur Assoc Fish Pathol 10:21-23

Meyers TR (2000) Standard necropsy procedures for fish. In: Meyers TR (ed) Fish pathology section laboratory manual, 2nd edn. Comm Fish Div, Alaska Dept Fish and Game, Juneau, AK, p 3-1-3-6

Meyers TR, Short S, Farrington C, Lipson K, Geiger HJ, Gates R (1993) Comparison of the enzyme-linked immunosorbent assay (ELISA) and the fluorescent antibody test (FAT) for measuring the prevalences and levels of Renibacterium salmoninarum in wild and hatchery stocks of salmonid fishes in Alaska, USA. Dis Aquat Org 16:181-189

Michak P, Smith CE, Hopper K (1992) Erythrocytic inclusion body syndrome: a light and electron microscopic study of infected erythrocytes of chinook Oncorhynchus tshawytscha and coho O. kisutch salmon. Dis Aquat Org 12: $229-233$

Okamoto N, Takahashi K, Maita M, Rohovec JS, Ikeda Y (1992) Erythrocytic inclusion body syndrome: susceptibility of selected sizes of coho salmon and of several other species of salmonid fish. Gyobyo Kenkyu 27:153-156

Palmer R, Soutar RH, Branson EJ, Southgate PJ, Drinan E, Richards RH, Collins RO (1992) Mortalities in Atlantic salmon, Salmo salar L., associated with pathology of the melano-macrophage and haemopoietic systems. J Fish Dis 15:207-210

Piacentini SC, Rohovec JS, Fryer JL (1989) Epizootiology of erythrocytic inclusion body syndrome. J Aquat Anim Health 1:173-179

Rodger HD, Richards RH (1998) Observational study of erythrocytic inclusion bodies in farmed Atlantic salmon, Salmo salar L., in the British Isles. J Fish Dis 21:101-111

Rodger HD, Drinan EM, Murphy TM, Lunder T (1991) Observations on erythrocytic inclusion body syndrome in Ireland. Bull Eur Assoc Fish Pathol 11:108-111

Romalde JL, Magarinos B, Fouz B, Bandin I, Nunez S, Toranzo AE (1995) Evaluation of BIONOR mono-kits for rapid detection of bacterial fish pathogens. Dis Aquat Org 21:25-34

Santos Y, Romalde JL, Bandin I, Magarinos B, Nunuz S, Barja JL, Toranzo AE (1993) Usefulness of the API-20E system for the identification of bacterial fish pathogens. Aquaculture 116:111-120

Takahashi K, Okamoto N, Kumagai A, Maita M, Ikeda Y, Rohovec JS (1992) Epizootics of erythrocytic inclusion body syndrome in coho salmon cultured in seawater in Japan. J Aquat Anim Health 4:174-181

Urawa S (1993) Effects of Ichthyobodo necator infections on seawater survival of juvenile chum salmon (Oncorhynchus keta). Aquaculture 110:101-110

Watanabe K, Karlsen M, Devold M, Isdal E, Litlabo A, Nylund A (2006) Virus-like particles associated with heart and skeletal muscle inflammation (HSMI). Dis Aquat Org 70:183-192 